\title{
Development of Computational-based Visualization Method in Physical Chemistry Practical Course
}

\begin{abstract}
Gani Purwiandono
Chemistry Department, Universitas Islam Indonesia, Kampus Terpadu UII Jalan Kaliurang Km 14,5, Yogyakarta

Email: gani_purwiandono@uii.ac.id

Abstract: Study on the development of computational-based visualization method in Physical Chemistry practical course has been carried out. The study was carried out by combining the conventional method and the visualization using the software. This combination class then was compared to the conventional class of the practical course. The cognitive evaluation showed that the distribution of students' understanding for the supporting theory of the practical course was not significantly different. The students had relatively the same level of understanding regarding the supporting theory. The evaluation of learning outcomes and the distribution of final grade showed that the class which combined the conventional and visualization method gave a positive result in the learning process
\end{abstract}

Keyword : Physical Chemistry practical course, computational-based visualization method, learning process

\section{Introduction}

Physical Chemistry practical course is a compulsory course for the students in Chemistry Department of Universitas Islam Indonesia. This course is given in the second year, aiming at giving the soft skill related to the laboratory work for the students. Through this course, students are expected to achieve the basic competency which is the ability to apply the theories of Physical Chemistry related to energy, reaction rate, and thermodynamics.

The learning process of Physical Chemistry practical course often does not give a satisfying theoretical description for the students. Thus, the American Chemical Society and the Journal of Chemical Education are making the development of the learning process for Physical Chemistry a focus in Chemistry learning process so that the learning process of Chemistry can be conducted more comprehensively (Ango, 2002; Cook, 2006; Gilbert et al., 2007; Davrut 2008).

One of the problems related to the learning process of Physical Chemistry practical course faced by Chemistry Department of Universitas Islam Indonesia in the year 2015 is that approximately $80 \%-90 \%$ of the students did not understand the theories that support the practical course. Therefore, a new method that can give an easy-tounderstand explanation related to the theory is needed. In this study, the development of visualization method is used to increase the students' understanding related to the theories that support the Physical Chemistry practical course. 


\section{Literature Review}

Physical Chemistry course is often assumed to be more difficult than other courses in Chemistry. There are many physical and mathematical approaches used to explain the chemical phenomena or a reaction. The limited learning facilities make the Physical Chemistry learning process more difficult. Many efforts have been carried out to increase the appreciation, interest, and understanding of the students for the course above (Zielinski and Schwenz, 2004; Hanisa, 2012; Fatichatul, 2014).

The Crystal software is one of the software in Physical Chemistry and is developed for the visualization of thermodynamics, kinetics, and energy. This software can convert the equation and physical parameters into a numerical form which is much easier to understand (Hasruddin, 2009; Ozqelen, 2012). The use of the computational-based visualization approach in the design of the learning process of Physical Chemistry practical course focuses on giving the theoretical concept, Thus, the quality of students' understanding can increase (Arad and Blonder, 2010). In this study, the development concept is carried out for an improvement for the development of the Physical Chemistry practical course substance. Also, the computational-based visualization method is used in the learning process. The computational-based visualization method given at the end of each practical course session is expected to increase the students' understanding related to the supporting theory of the practical course, and those theories can be firmly entrenched in their understanding.

\section{Method}

The study was conducted in Chemistry Department, Faculty of Mathematics and Science of Universitas Islam Indonesia, Yogyakarta. The study was conducted for four months, starting from August to December 2016. The subject of the study was the thirdsemester students. The Physical Chemistry practical course classes were divided into two classes. One class was conducted using the conventional method for teaching Physical Chemistry practical course, and the other used the combination between the computational-based visualization and the conventional method.

The applied learning model refered to the curriculum for Physical Chemistry practical course in Chemistry Department of Universitas Islam Indonesia as given in Table 1. The visualization method used the Gaussian09 and Crystal14 software. These software helped the students to generate the theoretical data and compare them to the data they got from the laboratory work. The students would gain an experience related to the learning process for laboratory soft skill and ability to operate the computer for supporting the basic theory of the practical course.

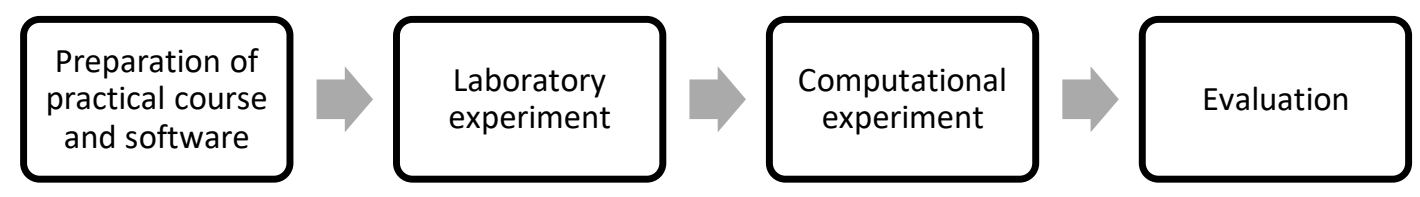

Figure 1. Design of the Development Method 
Table 1. Physical Chemistry Practical Course Topics

\begin{tabular}{clc}
\hline No. & \multicolumn{1}{c}{ Practical Work } & Computational and practical Approach \\
\hline 1 & Thermochemistry & $\sqrt{ }$ \\
2 & Isotherm adsorption & $\sqrt{ }$ \\
3 & Viscosity and activation energy & $\sqrt{ }$ \\
4 & Solubility as the temperature & $\sqrt{ }$ \\
& function & $\sqrt{ }$ \\
5 & Kinetic of phenolphthalein & \\
& solubility in alkaline solution & \\
\hline
\end{tabular}

The stages of learning model include:

\section{Preparation}

The evaluation of students' understanding of the basic theories that support the practical course was conducted using CBCE (Computer Based Competence Evaluation) system. This aimed to know how far the students have understood the theories in Physical Chemistry and the software as well as the multimedia technology. The evaluation in this stage resulted in the cognitive data of the students related to the program.

\section{Laboratory work}

In this stage, the conventional and the combination classes were given the same action that is the students must conduct the laboratory work according to the given topic as listed in Table 1.

3. Computational practical work

The students in combination class were given the materials and special training to be able to operate the software for the simulation of the practical course they have previously conducted. The students in the conventional class were not given those actions. In this stage, the author can evaluate the physio motoric of the students regarding the given program.

\section{Evaluation}

At the end of the program, the evaluation by involving both classes was conducted. With the same evaluation method, the data regarding the success of the program based on the previously set indicators. 


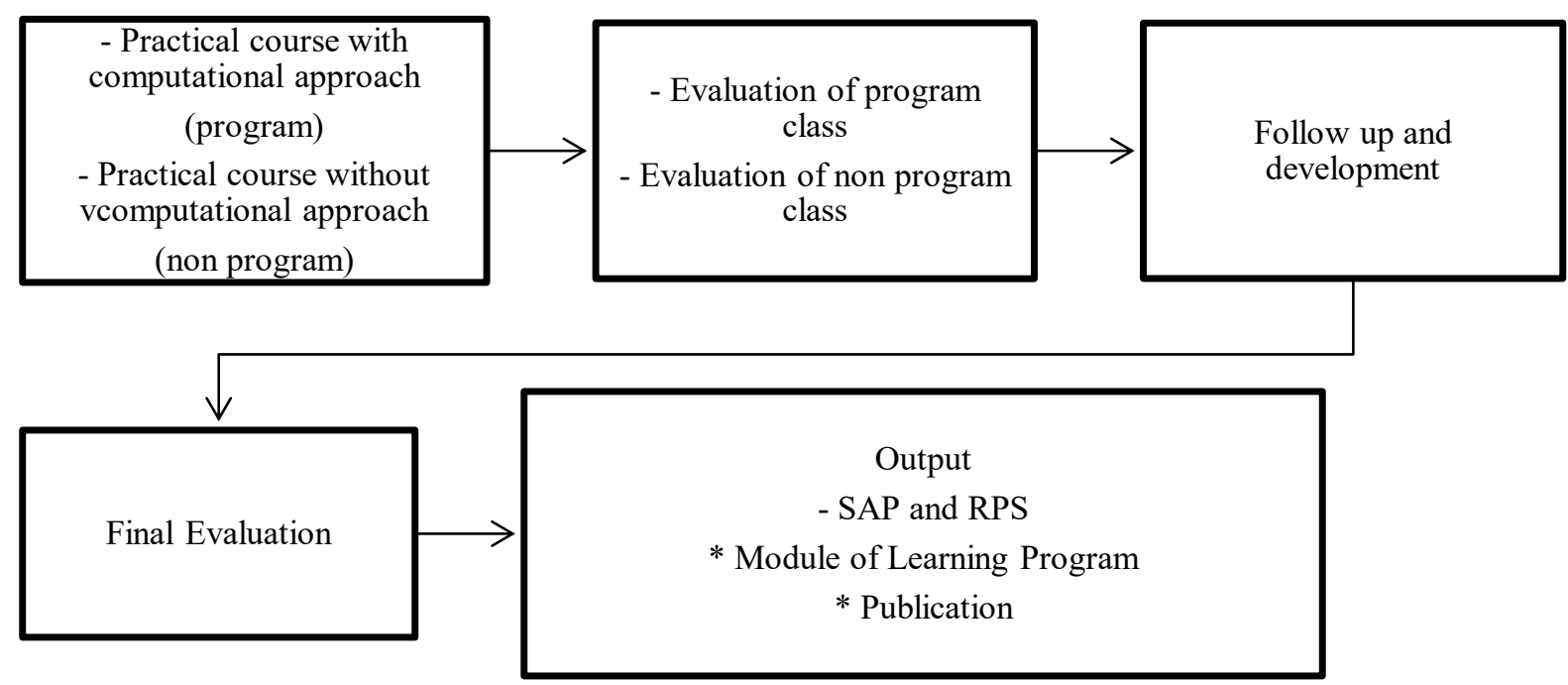

Figure 2. Design of the class

The output of this evaluation is SAP (Course Plan), RPS (Course Plan for One Semester), module, etc.

\section{Result}

The evaluation of students ability related to the computational practical work is given in Figure 3.

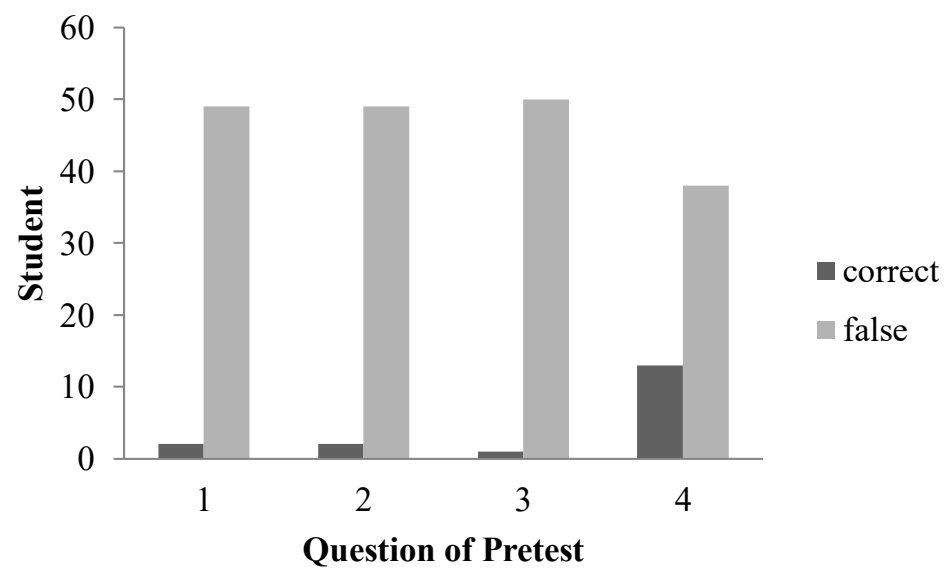

Figure 2. Evaluation of pre-practical course 


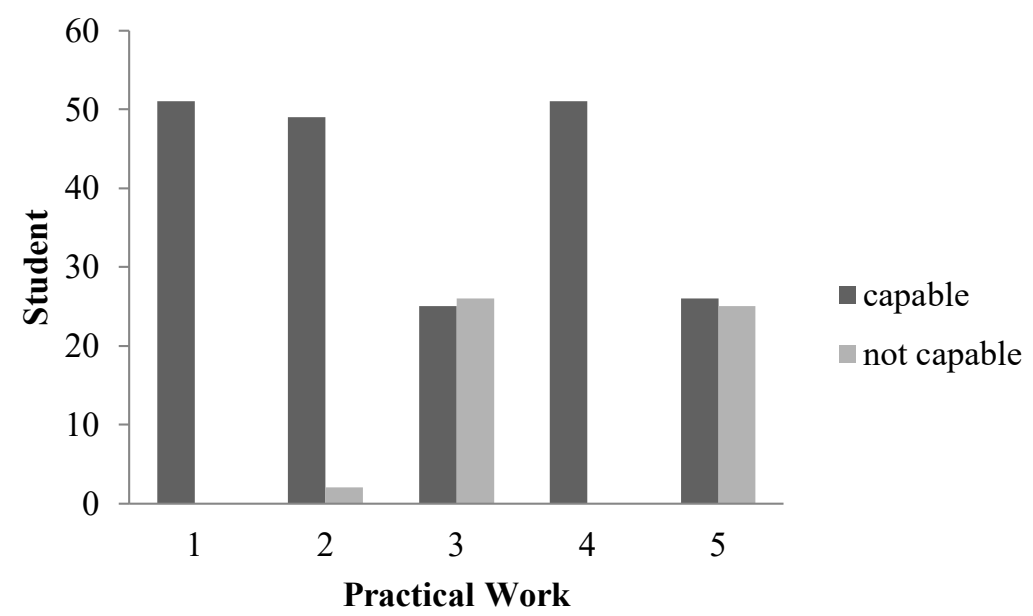

Figure 3. Evaluation of the computational practical course

Figure 3 shows the evaluation of the students' response to the given visualization methods.

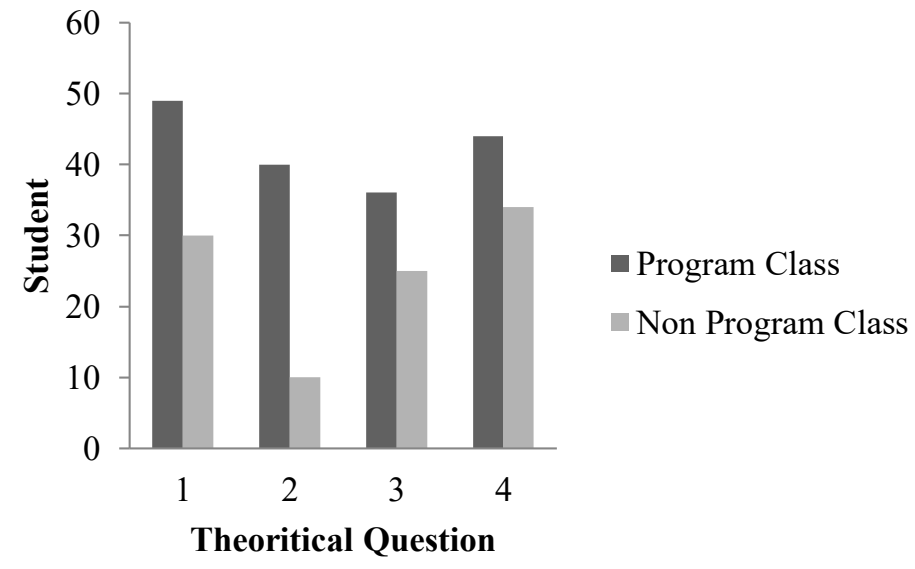

Figure 4. Evaluation of the Final Program

Table 2. Table of the Learning Outcomes and Assessment

\begin{tabular}{|c|c|c|c|}
\hline No & Learning Outcomes & Question & Assessment \\
\hline \multirow[t]{7}{*}{1} & LO 13: Mastering the theoretical & Energetics & 1. Understanding \\
\hline & concepts of structures and & Question: & 2. Knowledge \\
\hline & properties and the changes of & 1. In the experiment of solubility as a function of & \\
\hline & matter including the energy and & temperature (theory and computational), the students & \\
\hline & kinetics & carry out the experiment related to the solubility of & \\
\hline & & $\mathrm{Ca}(\mathrm{OH})_{2}$ and $\mathrm{H}_{2} \mathrm{C}_{2} \mathrm{O}_{4}$. How can you describe the & \\
\hline & & results and conclusion of the experiment? & \\
\hline \multirow[t]{4}{*}{2} & LO 14: Mastering the operational & Thermal reaction & 1. Analysis \\
\hline & knowledge including the & Question: & 2. Synthesis \\
\hline & functions, how to operate & 1. Explain how is the principle of the determination of & 3. Evaluation \\
\hline & instruments in chemistry and & heat of the reaction using calory meter and explain the & \\
\hline
\end{tabular}




\begin{tabular}{llll}
\hline \multicolumn{2}{l}{$\begin{array}{l}\text { analysis of data and information } \\
\text { from the instruments }\end{array}$} & obtained data. & \\
\hline 3 & LO 19: Having an ability to use & Computational-visualization Practical Work & $\begin{array}{l}\text { Students are able or not } \\
\text { able to use the software } \\
\text { software to perform analysis and } \\
\text { synthesis in physical chemistry }\end{array}$ \\
\hline 4 & LO 23: Understanding and & Solubility & 1. Knowledge \\
& $\begin{array}{l}\text { mastering the analytical skills in } \\
\text { physical chemistry }\end{array}$ & Question: & 2. Students \\
& 1. How is the theoretical principle of viscosity? How & Understanding \\
& is the viscosity determined in the experiment of & \\
& viscosity and activation energy? & \\
\hline
\end{tabular}

Table 2 shows the assessment for the attainment of learning outcomes and Figure 5 shows the distribution of the final grade for Physical Chemistry practical course.

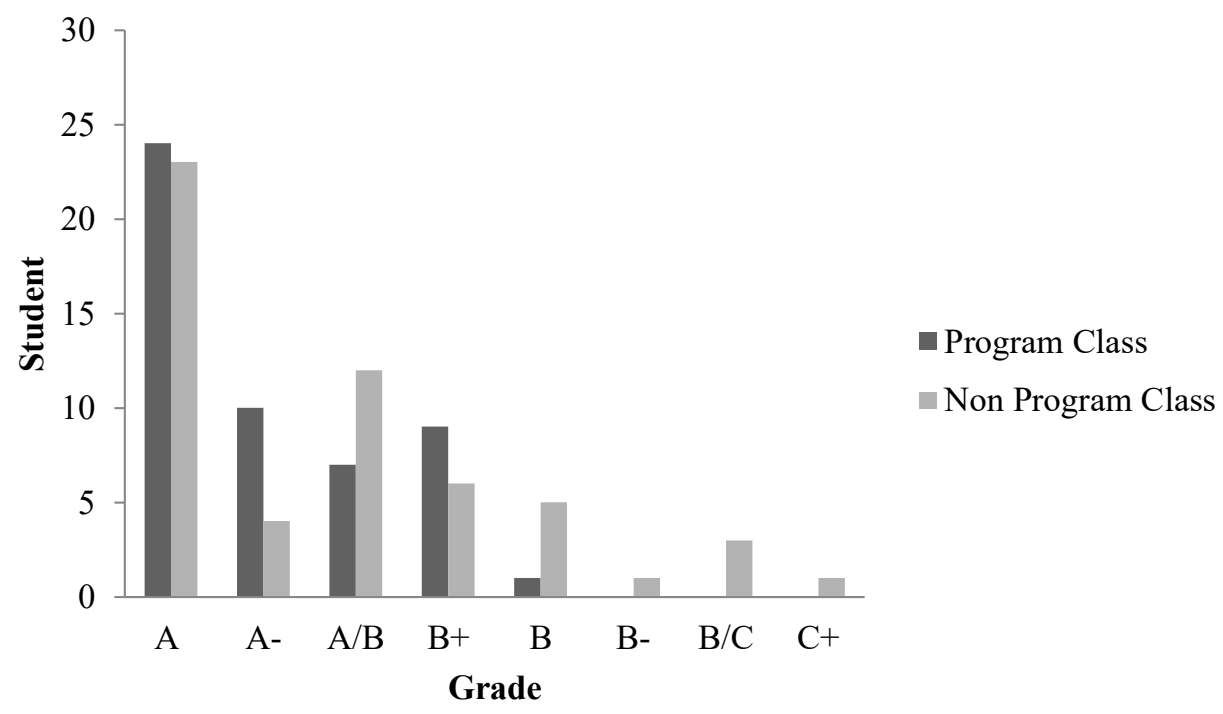

Figure 5. Final Grade for Physical Chemistry Practical Course

\section{Discussion}

The visualization method for Physical Chemistry practical course is an effort to increase the students' understanding of the supporting theories of the practical course. The evaluation was conducted to assess the students' understanding of Physical Chemistry theories. The evaluation was conducted through CBCE. The students were given four questions related to supporting theories of the practical course. The students consisted of 51 second year students. The result is presented in Figure 2. Figure 2 shows that $90 \%$ of the students are not able to answer the questions related to the supporting theories of the practical course. Thus, the visualization program for Physical Chemistry practical course will be applied or given to all students.

The evaluation of the program is not only conducted based on the involvement of all students in the program during the laboratory work but also based on the ability of the 
students in operating the software and modifying the data according to the procedures of the experiment. Figure 3 shows the evaluation of the students in responding the given visualization methods. There are only 5 data of experiments as listed in Table 1. For the critical micelle concentration and enthalphy of gelatine in various temperature, the software are unable to perform the modeling on the evaluation of molecular dynamics. In thermochemistry, adsorption isothermal and solubility as a function of temperature experiments, the response of the students in conducting the independent practical course to obtain and interpret the data seems good. However, in the experiment of viscosity and activation energy and the experiment of the kinetics of phenolphthalein dissociation in alkaline solution did not run as expected. This is because, in those experiments, an advanced skill in inputting data into the software is needed, while the students will take the course related to data inputting using computational software in the next semester $\left(4^{\text {th }}\right.$ semester $)$.

The evaluation of learning outcomes attainment was conducted at the end of the program through final test method. This evaluation was conducted to assess the success level of the program as well as the learning outcomes attainment. Figure 4 shows the evaluation of students' ability in answering the theoretical questions related to the practical course they have conducted in the laboratory. It is seen that there is an increase in the ability of the students, in which the visualization method is applied, to answer the supporting theories of the practical course.

The attainment of the course learning outcomes of both classes was compared. Table 2 shows the assessment for learning outcomes attainment and Figure 5 shows the distribution of the final grade for Physical Chemistry practical course.

\section{Conclusion}

The synchronization between theories and laboratory work for Physical Chemistry practical course can be performed using the computational-based visualization method. The success of the program can be seen from the result of the cognitive and phsyo motoric evaluation of the students. The use of the facilities in the computational laboratory gives a positive value for the learning process in Physical Chemistry practical course.

\section{Acknowledgments}

The author is grateful to the Directorate of Academic Development of Universitas Islam Indonesia for providing the financial supports for this work.

\section{References}

[1] Arad T and Blonder R 2010 Continuous Symmetry \& Chemsitry Teachers: Learning Advanced Chemistry Content Through Novel Visualization Tools

[2] Cook M 2006 Visual representations in science education: The influence of prior knowledge and cognitive load theory on instructional design principles Science education 90 1073-1091. doi:10.1002/sce 
[3] Gilbert JK Reiner M Nakhleh M 2007 Visualization: Theory and Practice in Science Education. Springer Science \& Business Media

[4] Zielinski TJ and Schwenz RW. 2001. Teaching Chemistry in the New Century: Physical Chemistry J.Chem.Educ. 2001781 173-1 174146

[5] Ango M 2002 Mastery of Science Process Skills and Their Effective Use in the Teaching of Science: An Educology of Science Education in the Nigerian Context. International Journal of Educology 16 (1): 11-30

[6] Davut H 2008 The Examination of the Basic Skill Levels of The Students' in Accordance with the Perceptions of Teachers, Parents and Students International Journal of Instruction 1(2): 39-56

[7] Hanisa D 2012 Model Kegiatan Laboratorium Berbasis Problem Solving Pada Pembelajaran Gelombang Dan Optik Untuk Meningkatkan Keterampilan Proses Sains Mahasiswa Jurnal Exacta 2 (10): 148 - 155

[8] Ozqelen S 2012 Students Science Skill Within a Cognitve Domain Framework Journal of Mathematics, Science, \& Technology Education 8 (4): 283 - 292

[9] Hasruddin 2009 Peran Multi Media Dalam Pembelajaran Biologi Jurnal Tabularasa PPS Unimed 2 (6): 149 - 160

[10] Fatichatul F 2014 Karakteristik Panduan Praktikum Kimia Fisika Bervisi-Sets Untuk Meningkatkan Keterampilan Proses Sains Jurnal Pendidikan Sains 1 (2): $20-25$ 